\title{
Reverse epidemiology, obesity and mortality in chronic kidney disease: modelling mortality expectations using energetics
}

Citation for published version (APA):

Speakman, J. R., \& Westerterp, K. R. (2010). Reverse epidemiology, obesity and mortality in chronic kidney disease: modelling mortality expectations using energetics. Blood Purification, 29(2), $150-7$. https://doi.org/10.1159/000245642

Document status and date:

Published: 01/01/2010

DOI:

10.1159/000245642

Document Version:

Publisher's PDF, also known as Version of record

Document license:

Taverne

Please check the document version of this publication:

- A submitted manuscript is the version of the article upon submission and before peer-review. There can be important differences between the submitted version and the official published version of record.

People interested in the research are advised to contact the author for the final version of the publication, or visit the DOI to the publisher's website.

- The final author version and the galley proof are versions of the publication after peer review.

- The final published version features the final layout of the paper including the volume, issue and page numbers.

Link to publication

\footnotetext{
General rights rights.

- You may freely distribute the URL identifying the publication in the public portal. please follow below link for the End User Agreement:

www.umlib.nl/taverne-license

Take down policy

If you believe that this document breaches copyright please contact us at:

repository@maastrichtuniversity.nl

providing details and we will investigate your claim.
}

Copyright and moral rights for the publications made accessible in the public portal are retained by the authors and/or other copyright owners and it is a condition of accessing publications that users recognise and abide by the legal requirements associated with these

- Users may download and print one copy of any publication from the public portal for the purpose of private study or research.

- You may not further distribute the material or use it for any profit-making activity or commercial gain

If the publication is distributed under the terms of Article $25 \mathrm{fa}$ of the Dutch Copyright Act, indicated by the "Taverne" license above, 


\title{
Reverse Epidemiology, Obesity and Mortality in Chronic Kidney Disease: Modelling Mortality Expectations Using Energetics
}

\author{
John R. Speakman ${ }^{\mathrm{a}} \quad$ Klaas R. Westerterp ${ }^{\mathrm{b}}$ \\ ${ }^{a}$ Aberdeen Centre for Energy Regulation and Obesity, Institute of Biological and Environmental Sciences, \\ University of Aberdeen, Aberdeen, UK; ${ }^{b}$ Department of Human Biology, University of Maastricht, \\ Maastricht, The Netherlands
}

\section{Key Words}

Reverse epidemiology $\cdot$ Original epidemiology $\cdot$ Obesity paradox $\cdot$ Thrifty gene hypothesis · Daily energy expenditure $\cdot$ Doubly labelled water $\cdot$ Dialysis $\cdot$ Wasting $\cdot$ Cachexia

\begin{abstract}
Background/Aims: Obesity is a predisposing factor for chronic illnesses such as type 2 diabetes, heart disease and cancer. In chronic kidney disease (CKD), the effect of obesity on mortality is reversed. Obese patients appear protected. Two ideas have been advanced to explain this 'reverse epidemiology'. First, obesity may buffer patients from wasting. Second, fat may sequester uraemic toxins leading to a systematic error in the prescription of dialysis. Our aim was to use data on the scaling of daily energy expenditure, fat and lean tissue mass to predict the pattern of variation in mortality with obesity under the contrasting hypotheses. Methods: We used data on daily energy demands measured using the doubly labelled water technique and body composition collected on a cohort of 503 individuals to model the expected impacts of wasting and fat sequestration/underdialysis on mortality. Results: A model predicting mortality due to wasting replicated the mortality pattern of the obesity paradox. However, quantitatively the beneficial effect of
\end{abstract}

being fat was predicted to be much larger than that observed in the actual CKD population. Similar results were found for the fat sequestration/underdialysis hypothesis, but in this case the discrepancy was smaller. Discussion: These models tend to support the fat sequestration and underdialysis idea more than the wasting hypothesis. In part (or in whole) this may be because of inadequacies in the model construction which are currently based on rather crude assumptions. Refinement of the models may enable better tests between alternative ideas for the obesity paradox.

Copyright $\odot 2010$ S. Karger AG, Basel

\section{Background}

Since the 1960s there has been an enormous increase in levels of body fatness in both the western world $[1,2]$ and more recently throughout developing nations $[3,4]$. By the conventional definitions of obesity (body mass index, BMI >30) and overweight (BMI>25), the population in the USA that is obese has increased from under $5 \%$ in 1960 to over $25 \%$ in $2004[1,5]$. This increase has been matched by an even greater explosion in the numbers of people that are overweight (increasing from 10 to 35\%). The largest proportional increase has been in the mor-

\section{KARGER}

Fax +41613061234 E-Mail karger@karger.ch www.karger.com
(C) 2010 S. Karger AG, Base

$0253-5068 / 10 / 0292-0150 \$ 26.00 / 0$

Accessible online at:

www.karger.com/bpu
John R. Speakman

Aberdeen Centre for Energy Regulation and Obesity

Institute of Biological and Environmental Sciences, University of Aberdeen Aberdeen AB24 2TZ (UK)

Tel. +44 1224272 879, Fax +44 1224272 396, E-Mail j.speakman@abdn.ac.uk 
bidly obese $(\mathrm{BMI}>40)[6]$. Obesity is a major health problem because it increases the risk for a number of chronic illnesses, the most significant of which is type 2 diabetes [7]. Matched with the increased risk of type 2 diabetes is an increased risk for cardiovascular disease $[8,9]$, fatty liver disease [10] and cancer $[11,12]$.

In marked contrast to the effects of obesity on mortality in the general population, it has become clear over the past 25 years that for patients with chronic kidney disease (CKD), and particularly those with end-stage renal disease (ESRD), who only remain alive if maintained on regular dialysis, the association between obesity and mortality risk is the opposite: fatter individuals have a lower mortality risk and therefore tend to survive longer [1321]. This pattern has been repeatedly demonstrated in many independent studies including some cohort studies containing in excess of 400,000 individuals [22]. The effect appears to be independent of the actual cause of death, and the impact of elevated body fatness appears to be protective right up to very high BMI values $(>35)$ that have been typically called 'morbid obesity' reflecting the normally extremely negative health effects of BMI in this range. The effect is observed in both males and females, and in Caucasians, African Americans and Hispanics. This phenomenon, whereby in some special circumstances the traditionally ascribed risk factors for mortality become protective, has been termed 'reversed epidemiology' or 'the obesity paradox' $[21,23,24]$.

There has been a diversity of ideas that might explain the obesity paradox [25] including the suggestion that it may reflect only a statistical artefact or be a consequence of selection bias in those patients who survive to ESRD, since most patients with CKD will die before reaching this ultimate diagnosis [23]. The fact that the paradox reverses following transplantation [26] however suggests that it reflects a true biological phenomenon in need of explanation. Moreover, the 'obesity paradox' generates some important practical conundrums. For example, should people with ESRD be encouraged to lose weight like the rest of the population, or as a precursor to transplantation surgery, if this in fact increases rather than decreases their mortality risk?

Two ideas have emerged as dominant potential explanations of the obesity paradox in ESRD. The first suggestion is that obesity has two contrasting influences on mortality risk which are apparent over different time domains: long and short $[17,25]$. The first 'traditional' epidemiological effect is that increased obesity leads to increased risk of chronic disease. Although this is called the 'traditional' epidemiological effect of obesity, in fact we have only become aware of this effect over the past 50 or so years. This is because the time domain over which this impact of obesity becomes apparent is very long (decades). We have only become aware of this negative effect of obesity in modern times because it is only with the advent of modern health care, the invention of antibiotics and the virtual elimination of death from epidemic diseases in the west that people have lived long enough for these negative impacts of obesity to become apparent. By this argument the 'original' epidemiological effect of obesity, which acts over a much shorter time domain, may in fact have been protective.

The classic embodiment of this 'original' positive epidemiology of obesity effects on mortality is the 'thrifty gene hypothesis' [27]. The 'thrifty gene' idea is that historically, human populations were exposed to cyclic periods of feast and famine. Under these conditions, it is suggested that selection would favour individuals that had genes allowing them to rapidly deposit body fat during periods of feast, because these fatter individuals would then have greater reserves to get them through the subsequent periods of famine. Although Neel [27] emphasised increased survival as the primary selective advantage, more recent studies have pointed out that a greater selective benefit may actually be that obese people could retain greater fertility during the famine periods [28].

By this argument the 'reverse epidemiology' observed in patients with CKD may in fact be a return to the 'original epidemiology' which emphasises the short-term benefits of obesity in situations of severe negative energy balance (such as famines). In effect the thrifty gene hypothesis posits that the modern epidemics of obesity and diabetes are the unfortunate consequences of embedding this previously advantageous genotype in a modern environment where food is readily available and easily obtained, allowing individuals to deposit enormous fat reserves in preparation for a famine that never comes. Perhaps then CKD is in effect the equivalent of a famine that the obese patient is prepared for, but the lean patient is not. The fact that CKD is a state of negative energy balance is supported by the observation that CKD patients very often experience profound wasting. Moreover, this idea is supported by the fact that weight loss is an independent risk factor for mortality in CKD, while weight gain is protective [15].

The second explanation of the obesity paradox is that it is in part a medical artefact based on the procedures used to prescribe dialysis treatment $[19,20,29-33]$. The specific suggestion is that uraemic toxins are generated 
principally by the visceral body compartment. This compartment is relatively large in smaller individuals so the production of harmful metabolites is relatively greater in smaller individuals [33]. This effect is exacerbated by the fact that in larger individuals these metabolites may be diluted in a greater volume of body water, and probably most importantly, sequestered into fat tissue [34]. Current practice is that the dialysis dose is based on the distribution volume of urea $(\mathrm{V})$ which approximates the body water volume. Specifically the dialysis dose is the intensity of dialysis $\mathrm{K}$ multiplied by time $\mathrm{t}$ divided by $\mathrm{V}$ $(\mathrm{Kt} / \mathrm{V})$. Clearly if uraemic toxins are produced at elevated rates in smaller individuals and in larger individuals are sequestered into fat, then smaller individuals will be relatively underdialysed [33]. It is suggested that this underdialysis may generate the differential mortality effect in ESRD, since the dialysis dose is related to mortality [35, 36].

Our curiosity in these alternative hypotheses stems from an interest in the validity of the idea that obesity once had a positive short time domain advantage, i.e. the notion of 'original epidemiology' as embodied in the 'thrifty gene hypothesis'.

In fact, we have previously shown that the thrifty gene idea has several basic flaws [37, 38]. First, if selection really had been so intense in our historical past due to the frequency of famines, and obesity was so advantageous, then it is difficult to understand why the favourable alleles for obesity have not spread through the entire population, making us all overweight or obese. Second, a detailed analysis of famine mortality reveals no supportive evidence that obese people survive and lean people die. Most mortality in famines falls on children and older people for reasons that are generally unrelated to their BMI (i.e. infectious diseases and diarrhoea) but more related to poor food choice under severe hunger - for example eating corpses. Given the reality of starvation events, it seems unlikely that there was ever a positive original epidemiology for obesity that is effective in the short time domain. This does not mean that 'reverse epidemiology' cannot be a consequence of obesity protecting against negative energy balance and wasting, only that if this is the case, this effect is likely a modern phenomenon.

\section{Methods}

In this paper we will explore some ways that these two alternative hypotheses might be distinguished using information on daily energy demands and body energy storage patterns. The wasting hypothesis suggests that fatness protects against wasting. One way to view this is that the body fat and muscle is an energy store that persons draw on when they are in negative energy balance. When this reaches a critical low limit, there is no energy left in the store and this leaves the person unable to respond if a crisis happens such as a cardiovascular event. If this idea were correct, we would predict that the bigger the stores an individual carries, the longer it would be before he/she ran out of energy - explaining the basic 'obesity paradox'. Moreover, if individuals expended energy at a higher rate, they would similarly exhaust their stores more rapidly. There is a complexity here however because bigger people carrying greater stores also expend more energy, so the exact balance between these effects is not intuitively obvious. Can we use data on levels of fat storage and energy demands to model the likely pattern of impact of body fatness on mortality under the wasting hypothesis? To evaluate the wasting hypothesis, we need to know two things: daily energy demands as a function of body weight, and the levels of fat and muscle tissue in relation to body weight.

What does the underdialysis hypothesis predict? To model this hypothesis we also need to know two things. First, how the actual prescription varies with body size, and second, what the prescription should be. The actual prescription criterion for dialysis is $\mathrm{Kt} / \mathrm{V}$, so we can easily model this if we know how $\mathrm{V}$ varies with body weight. Knowing what the prescription 'should be' is mired in controversy [31, 32, 39, 40]. Potential suggestions have been that dialysis should be independent of body size ( $\mathrm{Kt}=\mathrm{con}$ stant), scaled to resting metabolic rate, scaled to high metabolic rate organ mass, scaled to surface area and scaled to the mass of visceral tissues. The merits and demerits of the alternatives have been discussed elsewhere. We see two components to this issue. One is how to predict the production of uraemic toxins in relation to body size. The second problem is the envisaged sequestration of these toxins by body fat. We propose here that uraemic toxins are likely generated in relation to daily energy demands (equivalent to average daily metabolic rate). Previous suggestions to scale dialysis to metabolic rate parameters such as resting metabolic rate have been criticised because the latter comprises many compartments of metabolism, such as from the heart and brain that likely contribute little to the production of uraemic toxins. For daily energy expenditure (DEE), the link to uraemic toxins may seem even more tenuous because DEE also comprises in large part energy expended on physical activity. Our reasoning for making this suggestion is as follows. The primary source of uraemic toxins probably stems from processed food intake, and over the long term, food intake has to be closely related to DEE. This argument is supported by the fact that when comparisons are made across different mammal species, several aspects of renal physiology such as creatinine clearance rates and glomerular filtration rates [41] scale similarly to body weight as DEE [42]. Given a model of uraemic toxin production, we also need to know how sequestration of these toxins is influenced by body fatness. The simplest way to model this is to assume a direct proportional uptake in relation to fat mass (FM). Hence the uraemic toxins in circulation that need to be cleared by dialysis should be proportional to DEE/ FM. If dialysis should be proportional to DEE/FM but is in fact scaled to $\mathrm{V}$, we can quantify the extent of underdialysis in relation to body weight from the ratio (DEE/FM)/V. Mortality should be directly proportional to this function. 

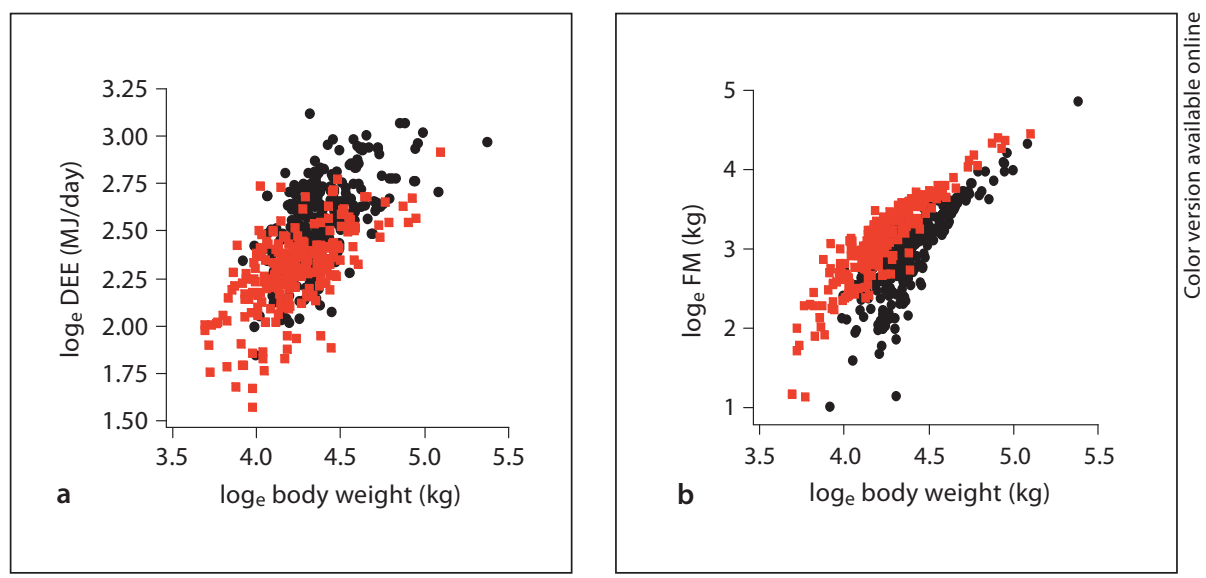

Fig. 1. a Effects of body weight and sex on DEE. Heavier individuals expend more, and at any given weight, females expend less than males. b Effects of body weight and sex on fat content. Heavier individuals and females store more fat. c Modelled effects of size on survival under a wasting model. d Actual pattern of mortality in CKD patients based on $>400,000$ subjects [22].
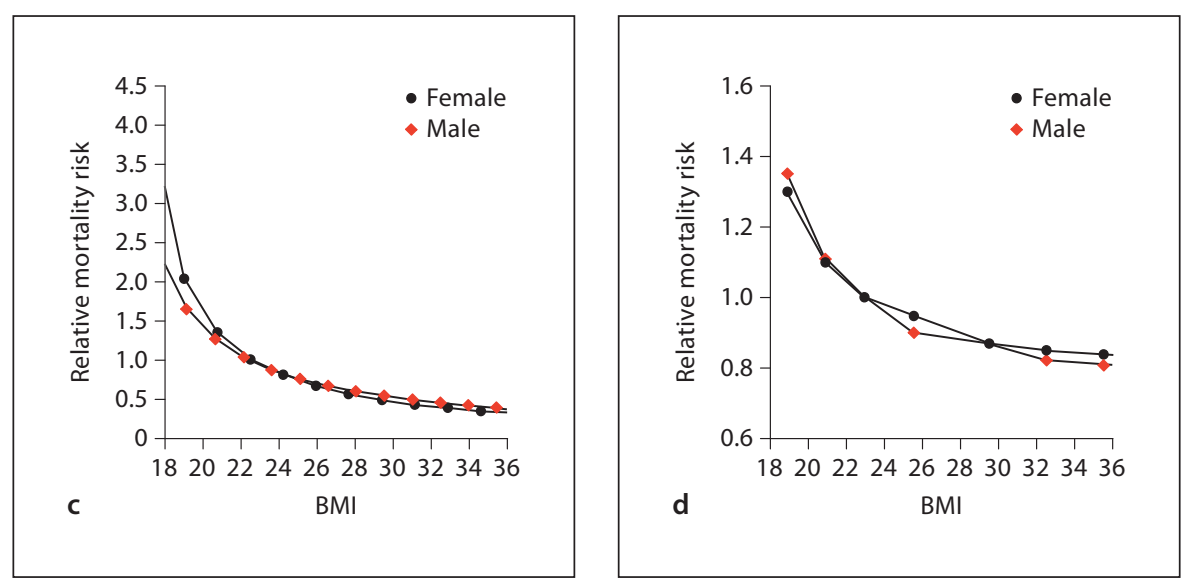

To construct these models that predict the exact form of the expected relations between BMI and mortality in ESRD, data were required on how daily energy demands, body water, fat and lean tissue masses all vary in relation to body weight. We used data for these traits in relation to body weight that were collected on a large cohort of individuals $(n=503)$ measured in Maastricht in The Netherlands using the doubly labelled water method [43]. We have utilised this cohort previously to explore aspects of daily energy demands in the context of the causality of obesity [44]. Details of the methodology used to collect the data and subject characteristics can be found in Westerterp and Speakman [44] and on the doubly labelled water method more generally in Speakman [43].

\section{Results}

\section{The Wasting Hypothesis}

Daily energy expenditure in this sample was dominated by two factors: body weight $(\mathrm{t}=16.8, \mathrm{p}<0.001)$ and sex $(t=10.31, p<0.001$; fig. 1a). On average a female at any given body weight expends about $0.17 \log _{\mathrm{e}}$ units less energy than a male of the same weight. At a median body weight of $76 \mathrm{~kg}$, this difference amounts to $5 \mathrm{MJ}$ of energy per day. Body fatness and body lean tissue content were also positively related to body weight $(\mathrm{t}=38.17$, $\mathrm{p}<$ $0.001)$ and $\operatorname{sex}(t=17.9, p<0.001$; fig. $1 b)$. This time, however, females had greater fatness than males. At the median body weight, this effect was equivalent to $9.5 \mathrm{~kg}$ extra fat tissue in a female, but the equivalent less in lean tissue. As individuals get heavier, the proportional contribution of fat to their body weight gets greater. Hence if an individual reduces his/her weight from 140 to $135 \mathrm{~kg}$, this $5-\mathrm{kg}$ weight loss comprises $4.1 \mathrm{~kg}$ fat and $0.9 \mathrm{~kg}$ lean tissue. In contrast, an individual reducing from 65 to 60 $\mathrm{kg}$ loses $2 \mathrm{~kg}$ fat and $3 \mathrm{~kg}$ lean tissue. Because fat contains more energy than lean tissue, the length of time that $5 \mathrm{~kg}$ of body weight can in theory sustain a person is much longer when they are heavier than when they are lighter.

However, this effect is potentially offset by the greater energy requirement of the larger person. To model the effects of body weight and gender on energy utilisation, we 

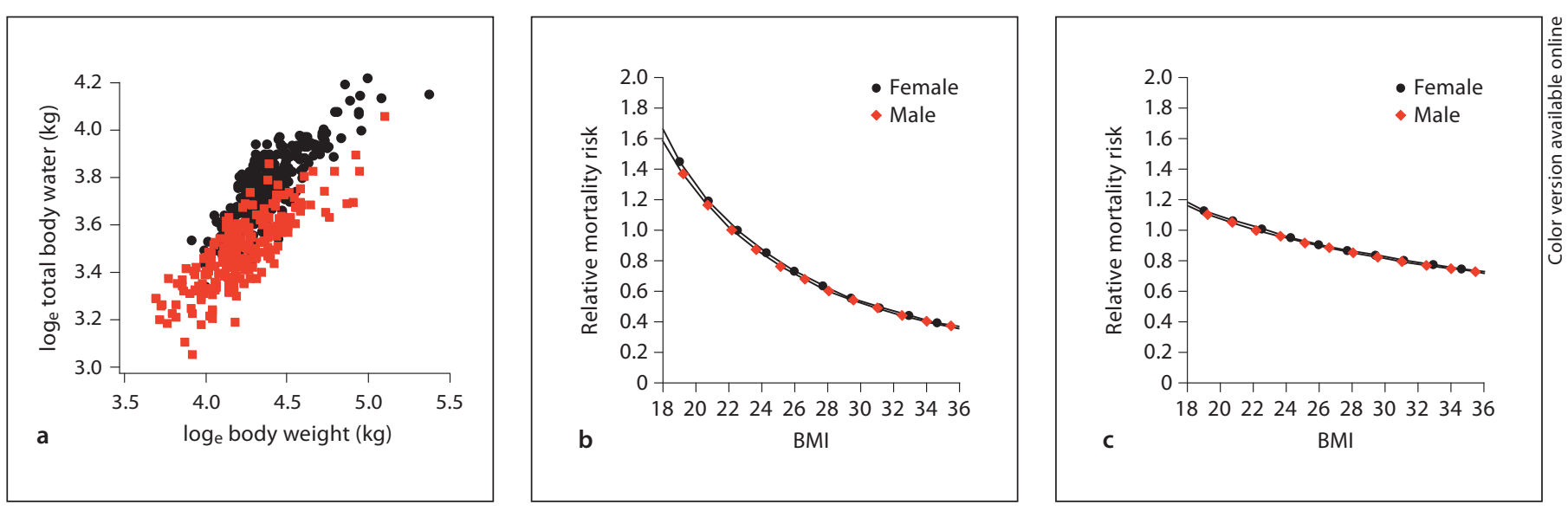

Fig. 2. a Effect of body weight on total body water. Bigger individuals and males have greater levels of total body water. b Modelled effect of body weight and sex on mortality under the sequestration of toxins and misprescribed dialysis hypothesis. $\mathbf{c}$ As $\mathbf{b}$ but with the relationship between fat sequestration capacity and volume nonlinear.

used the regression fits relating body weight to DEE, FM and fat-free mass. We used an incremental model with a fixed lower 'fatal' body weight of $45 \mathrm{~kg}$ for a woman and $55 \mathrm{~kg}$ for a man (equivalent to BMI values of 15.5 and 16.5 in typical-height females and males, respectively). We started with a body weight of $50 \mathrm{~kg}$ for females and $60 \mathrm{~kg}$ for males and calculated how long an individual of this weight would survive given their energy reserves of fat and lean tissue at this weight and their DEE. We then asked how long a female weighing $65 \mathrm{~kg}$ and a male weighing $70 \mathrm{~kg}$ would take to decrease in weight to 60 and 65 $\mathrm{kg}$, respectively, and we added this time to the time to reduce to 55 and $60 \mathrm{~kg}$. We iterated this process for weights up to $130 \mathrm{~kg}$ for men and $120 \mathrm{~kg}$ for women. At each weight these times reflect the available time before an individual would reduce to the fatal weight.

To convert these survival times into mortalities we took the inverse value and using an average height of 170 $\mathrm{cm}$ for females and $184 \mathrm{~cm}$ for males we then converted this relationship into the expected protection against wasting, as a function of BMI. These mortality rates were then calculated relative to that at a BMI of 22. The resultant expected mortality curves under the wasting model are shown in figure 1c. These can be directly compared with the actual reverse epidemiology mortality curves for males and females as a function of BMI for 418,055 CKD patients [22] (fig. 1d). The similarities in the shapes of the model prediction and the observed pattern of mortality are obvious. There are however some striking differences as well. Most notably, the extent of mortality difference between the high-BMI and low-BMI individuals predicted by the model (from 0.3 at $\mathrm{BMI}=35$ to 2.0 at $\mathrm{BMI}=19$ ) is much greater than that observed in the actual data (from 0.8 at $\mathrm{BMI}=35$ to 1.3 at $\mathrm{BMI}=19$ ). Moreover, the actual data show that female mortality was significantly lower than that of males at low BMI, but higher at high BMI [22], whereas the model data show the reverse expectation, male mortality being lower at low BMI and higher at high BMI. While qualitatively successful, the model was quantitatively lacking.

\section{The Sequestration and Underdialysis Hypothesis}

Since $\mathrm{V}$ is approximately equal to the body water volume and this value is derived as part of the doubly labelled water technique, this was easily obtained for our cohort (fig. 2a). Like fat-free mass and FM, the body water volume was similarly dependent on both body weight $(\mathrm{t}=31.8, \mathrm{p}<0.001)$ and $\operatorname{sex}(\mathrm{t}=22.9, \mathrm{p}<0.001)$. We modelled sequestration by fat assuming a linear sequestration rate in relation to fat mass (DEE/FM). We then quantified the extent of 'underdialysis' in relation to body weight from the ratio (DEE/FM)/V. If underdialysis is the problem, mortality should be directly related to this function. We made this calculation for males and females of different body weights between 45 and $120 \mathrm{~kg}$ for females and $55-130 \mathrm{~kg}$ for males using the relationship shown in figure 1a for DEE and figure 2a for V (= total body water), and then scaled this to the BMI calculated as above for the wasting hypothesis, and also normalised the data to the mortality at $\mathrm{BMI}=22$. The resultant plot of modelled 
mortality as a function of $\mathrm{BMI}$ is shown in figure $2 \mathrm{~b}$. This can similarly be compared with the actual mortality plot for the obesity paradox in figure 1d [22]. This pattern appears to fit the actual mortality data slightly better than the model based on the wasting hypothesis, although again there is a discrepancy in the predicted extent of the mortality effect of obesity, and this model predicts no difference between the sexes at all.

\section{Discussion}

Overall, these analyses suggest that the pattern of mortality in relation to BMI that is observed in reverse epidemiology during ESRD fits more closely with expectations derived from the sequestration of toxins and underdialysis hypothesis than the wasting hypothesis. It is important to recognise that the usefulness of such modelling exercises depends in large part on how well the model assumptions reflect the underlying physiology. In this sense, both models are likely to be imperfect - possibly seriously so. In the wasting model, we assumed that individuals survive during ESRD basically until they waste away. This assumption places a large premium on having large energy reserves and hence generates a large predicted mortality effect between high- and low-BMI individuals. In reality, however, patients with ESRD often show wasting, but seldom die directly of it, the most frequent causes of death being cardiac events or infectious diseases. Moreover, weight loss under dialysis may not be progressive and causal of secondary complications, but a secondary effect itself following infection [45]. The phenomenon of kidney disease wasting is therefore likely much more complex than our simple model assumes. For example, patients that exercise during ESRD have a better survival probability than sedentary patients [46], while a simple interpretation of wasting energetics would predict that they should use up their energy stores more rapidly and have greater mortality. The mechanisms by which wasting might be involved, or not, in mortality events in CKD is uncertain, and if such mechanisms were established it might allow refinement of the model and ultimately provide stronger support for this hypothesis.

Our assumptions about the sequestration capacity of fat and the production of uraemic toxins may be similarly suspect. Greater knowledge of these processes would allow similar refinement of the model predictions. For example, if uraemic toxins were sequestered by fat in relation to the cube root of its mass rather than linearly, then the resultant model predictions for mortality match much more closely the actual data (fig. 2c). There is, however, no physiological justification for this assumption over the linear model used to derive the prediction in figure $2 \mathrm{~b}$. Perhaps this means that attempting to test between the hypotheses using this type of energetic model is a flawed approach. We prefer the interpretation that refinement of the models with better founded information may still prove valuable for evaluating alternative explanations of the obesity paradox.

Despite our models broadly supporting the sequestration and underdialysis hypothesis, two independent factors lend additional support to the wasting hypothesis. First, the obesity paradox is also apparent in CKD patient populations that are not on dialysis [47]. This might be explained by the fact that a major aspect of the underdialysis idea is based around the sequestration of toxins by fat, which will presumably also pertain before patients reach ESRD and are prescribed any dialysis treatment. Second, however, other chronic illnesses that have a 'wasting' component to them also seem to exhibit reverse epidemiology and an obesity paradox [25, 48-51]. These include chronic heart failure, chronic obstructive pulmonary disease and cancer. Clearly, in these instances, sequestration of uraemic toxins by fat and underdialysis cannot be an important factor. Perhaps wasting and separate time domains of the impact of mortality from obesity really do generate an obesity paradox, but in ESRD this effect is exacerbated by the sequestration of toxins and underdialysis effects. That is, both hypotheses may be correct and contribute to the overall effect. Comparing the magnitude of the paradox in different circumstances may illuminate their contrasting roles. Moreover, perhaps deeper understanding of these wasting diseases may provide some useful insights into the supposed 'original' epidemiology effects of obesity.

\section{Acknowledgements}

We are grateful to Peter Kotanko and Nathan Levin for the invitation to prepare this work and present it at the 12th International Conference on Dialysis 'Advances in Chronic Kidney Disease 2010'. 


\section{References}

1 Ogden CL, Carroll MD, Curtin LR, McDowell MA, Tabak CJ, Flegal KM: Prevalence of overweight and obesity in the United States, 1999-2004. JAMA 2006;295:1549-1555.

-2 Ogden CL, Flegal KM, Carroll MD, Johnson CL: Prevalence and trends in overweight among US children and adolescents, 19992000. JAMA 2002;288:1728-1732.

-3 Kain J, Uauy R, Vio F, Albala C: Trends in overweight and obesity prevalence in Chilean children: comparison of three definitions. Eur J Clin Nutr 2002;56:200-204.

4 Likitmasku S, Kiattisathavee P, Chaichanwatanakul K, Punnakanta L, Angsusingha $\mathrm{K}$, Tuchinda C: Increasing prevalence of type 2 diabetes mellitus in Thai children and adolescents associated with increasing prevalence of obesity. J Pediatr Endocrinol Metab 2003;16:71-77.

5 Flegal KM, Troiano RP: Changes in the distribution of body mass index of adults and children in the US population. Int J Obes 2000;24:807-818.

-6 Sturm R: Increases in morbid obesity in the USA: 2000-2005. Public Health 2007;121: 492-496.

7 Whitlock G, Lewington S, Sherliker P, Clarke R, Emberson J, Halsey J, Qizilbash N, Collins R, Peto R, Lewington S, MacMahon S, Peto R, Aromaa A, Baigent C, Carstensen J, Chen Z, Clarke R, Collins R, Duffy S, Kromhout D, Neaton J, Qizilbash N, Rodgers A, Tominaga S, Tornberg S, Tunstall-Pedoe H, Whitlock G, Chambless L, De Backer G, De Bacquer D, Kornitzer M, Whincup P, Wannamethee SG, Morris R, Wald N, Morris J, Law M, Knuiman M, Bartholomew H, Smith GD, Sweetnam P, Elwood P, Yarnell J, Kronmal R, Kromhout D, Sutherland S, Keil J, Jensen G, Schnohr P, Hames C, Tyroler A, Aromaa A, Knekt P, Reunanen A, Tuomilehto J, Jousilahti P, VArtiainen E, Puska P, Kuznetsova T, Richart T, Staessen J, Thijs L, Jorgensen T, Thomsen T, Sharp D, Curb JD, Qizilbash N, Iso H, Sato S, Kitamura A, Naito Y, Benetos A, Guize L, Goldbourt U, Tomita M, Nishimoto Y, Murayama $T$, Criqui $M$, Davis $C$, Hart $C$, Smith GD, Hole D, Gillis C, Jacobs D, Blackburn H, Luepker R, Neaton J, Eberly L, Cox C, Levy D, D’Agostino R, Silbershatz H, Tverdal A, Selmer R, Meade T, Garrow K, Cooper J, Speizer F, Stampfer M, Menotti A, Spagnolo A, Tsuji I, Imai Y, Ohkubo T, Hisamichi S, Haheim L, Holme I, Hjermann I, Leren P, Ducimetiere P, Empana J, Jamrozik K, Broadhurst R, Assmann G, Schulte H, Bengtsson C, Bjorkelund C, Lissner L, Sorlie P, Garcia-Palmieri M, Barrett-Conner E, Criqui M, Langer R, Hart C, Smith GD, Hole D, Nakachi K, Imai K, Fang X, Li S, Buzina R, Nissinen A, Aravanis C, Dontas A, Kafatos A, Menotti A, Adachi H, Toshima H, Imaizumi T, Kromhout D, Nedeljkovic S, Ostojic M, Chen Z, Tunstall-Pedoe H, Nakayama T, Yoshiike N, Yokoyama T, Date C, Tanaka H, Keller J, Bonaa K, Arne- sen E, Tunstall-Pedoe H, Rimm E, Gaziano M, Buring JE, Hennekens C, Tornberg S, Carstensen J, Shipley M, Leon D, Marmot M, Clarke R, Collins R, Emberson J, Halsey J, Lewington S, Palmer A, Parish S, Peto R, Sherliker P, Whitlock G: Body-mass index and cause-specific mortality in 900,000 adults: collaborative analyses of 57 prospec-

tive studies. Lancet 2009;373:1083-1096.

8 Pi-Sunyer FX: The obesity epidemic: pathophysiology and consequences of obesity. Obesity Res 2002;10:97S-104S.

-9 Pi-Sunyer FX: The medical risks of obesity. Obesity Surg 2002;12:6S-11S.

10 Browning JD, Szczepaniak LS, Dobbins R, Nuremberg P, Horton JD, Cohen JC, Grundy SM, Hobbs HH: Prevalence of hepatic steatosis in an urban population in the United States: impact of ethnicity. Hepatology 2004; 40:1387-1395.

11 Calle EE, Kaaks R: Overweight, obesity and cancer: epidemiological evidence and proposed mechanisms. Nat Rev Cancer 2004;4: 579-591.

12 Calle EE, Rodriguez C, Walker-Thurmond $\mathrm{K}$, Thun MJ: Overweight, obesity, and mortality from cancer in a prospectively studied cohort of US adults. N Engl J Med 2003;348: 1625-1638.

13 Kalantar-Zadeh K, Kovesdy CP, Derose SF, Horwich TB, Fonarow GC: Racial and survival paradoxes in chronic kidney disease. Nat Clin Pract Nephrol 2007;3:493-506.

14 Kalantar-Zadeh K, Kopple JD: Obesity paradox in patients on maintenance dialysis. Obes Kidney 2006;151:57-69.

15 Kalantar-Zadeh K, Kuwae N, Wu DY, Shantouf RS, Fouque D, Anker SD, Block G, Kopple JD: Associations of body fat and its changes over time with quality of life and prospective mortality in hemodialysis patients. Am J Clin Nutr 2006;83:202-210.

16 Kalantar-Zadeh K, Abbott KC, Salahudeen AK: The paradox of the 'body mass index paradox' in dialysis patients: associations of adiposity with inflammation - reply. Am J Clin Nutr 2005;82:910-911.

17 Kalantar-Zadeh K, Abbott KC, Salahudeen AK, Kilpatrick RD, Horwich TB: Survival advantages of obesity in dialysis patients. Am J Clin Nutr 2005;81:543-554.

18 Kalantar-Zadeh K, Block G, Humphreys $\mathrm{MH}$, Kopple JD: Reverse epidemiology of cardiovascular risk factors in maintenance dialysis patients. Kidney Int 2003;63:793808 .

19 Hirachan P, Thijssen S, Levin NW, Kotanko $\mathrm{P}$ : Body composition and outcomes in chronic hemodialysis patients. Hemodial Basic Res Clin Trials 2008;161:108-114.

20 Kotanko P, Thijssen S, Kitzler T, Wystrychowski G, Sarkar SR, Zhu F, Gotch F, Levin NW: Size matters: body composition and outcomes in maintenance hemodialysis patients. Blood Purif 2007;25:27-30.
21 Abbott KC: Reverse epidemiology and obesity in maintenance dialysis patients. Kidney Int 2003;64:1138.

22 Johansen KL, Young B, Kaysen GA, Chertow GM: Association of body size with outcomes among patients beginning dialysis. Am J Clin Nutr 2004;80:324-332.

23 Kalantar-Zadeh K, Kilpatrick RD, Kuwae N, Wu DY: Reverse epidemiology: a spurious hypothesis or a hardcore reality? Blood $\mathrm{Pu}$ rif 2005;23:57-63.

24 Beddhu S: The body mass index paradox and an obesity, inflammation, and atherosclerosis syndrome in chronic kidney disease. Semin Dial 2004;17:229-232.

25 Kalantar-Zadeh K, Horwich TB, Oreopoulos A, Kovesdy CP, Younessi H, Anker SD, Morley JE: Risk factor paradox in wasting diseases. Curr Opin Clin Nutr Metab Care 2007; 10:433-442.

26 Schold JD, Srinivas TR, Guerra G, Reed AI, Johnson RJ, Weiner ID, Oberbauer R, Harman JS, Hemming AW, Meier-Kriesche HU: A 'weight-listing' paradox for candidates of renal transplantation? Am J Transplant 2007;7:550-559.

27 Neel JV: Diabetes mellitus: a 'thrifty' genotype rendered detrimental by 'progress'? Am J Hum Genet 1962;14:352-353.

28 Prentice AM, Hennig BJ, Fulford AJ: Evolutionary origins of the obesity epidemic: natural selection of thrifty genes or genetic drift following predation release? Int J Obes 2008; 32:1607-1610.

29 Kotanko P, Kuhlmann MK, Levin NW: Why adipose dialysis patients live longer - a hypothesis. Wien Klin Wochenschr 2007;119: 620-624.

30 Kotanko P, Levin NW: The impact of visceral mass on survival in chronic hemodialysis patients. Int J Artif Organs 2007;30:993999.

-31 Sarkar SR, Kotanko P, Heymsfeld SB, Levin NW: Quest for V: body composition could determine dialysis dose. Semin Dial 2007;20: 379-382.

- 32 Sarkar SR, Kuhlmann MK, Kotanko P, Zhu F, Heymsfield SB, Wang J, Meisels IS, Gotch FA, Kaysen GA, Levin NW: Metabolic consequences of body size and body composition in hemodialysis patients. Kidney Int 2006; 70:1832-1839.

33 Kotanko P, Levin NW: The impact of visceral mass on survival in chronic hemodialysis patients. Int J Artif Organs 2007;30:993999.

-34 Kalantar-Zadeh K, Kopple JD: Obesity paradox in patients on maintenance dialysis. Obes Kidney 2006;151:57-69.

35 Held PJ, Port FK, Wolfe RA, Stannard DC, Carroll CE, Daugirdas JT, Bloembergen WE, Greer JW, Hakim RM: The dose of hemodialysis and patient mortality. Kidney Int 1996; 50:550-556. 
-36 Wolfe RA, Ashby VB, Daugirdas JT, Agodoa LYC, Jones CA, Port FK: Body size, dose of hemodialysis, and mortality. Am J Kidney Dis 2000;35:80-88.

-37 Speakman JR: Thrifty genes for obesity, an attractive but flawed idea, and an alternative perspective: the 'drifty gene' hypothesis. Int J Obes 2008;32:1611-1617.

>38 Speakman JR: A nonadaptive scenario explaining the genetic predisposition to obesity: the 'predation release' hypothesis. Cell Metab 2007;6:5-12.

-39 Daugirdas JT, Levin NW, Kotanko P, Depner TA, Kuhlmann MK, Chertow GM, Rocco MV: Comparison of proposed alternative methods for rescaling dialysis close: resting energy expenditure, high metabolic rate organ mass, liver size, and body surface area. Semin Dial 2008;21:377-384.

-40 Daugirdas JT, Depner TA, Greene T, Kuhlmann MK, Levin NW, Chertow GM, Rocco MV: Surface-area-normalized Kt/V: a method of rescaling dialysis dose to body surface area-implications for different-size patients by gender. Semin Dial 2008;21:415-421.
41 Edwards NA: Scaling of renal functions in mammals. Comp Biochem Physiol 1975;52: 63-66.

42 Speakman JR: The cost of living: field metabolic rates of small mammals. Adv Ecol Res 2000;30:177-297.

43 Speakman JR: Doubly-Labelled Water: Theory and Practice. New York, Kluwer Academic Publishers, 1997.

44 Westerterp KR, Speakman JR: Physical ac tivity energy expenditure has not declined since the 1980s and matches energy expenditures of wild mammals. Int J Obes 2008;32: 1256-1263.

45 Kotanko P, Thijssen S, Usvyat L, Tashman A, Kruse A, Huber C, Levin NW: Temporal evolution of clinical parameters before death in dialysis patients: a new concept. Blood Purif 2009;27:38-47.

46 O'Hare AM, Tawney K, Bacchetti P, Johansen KL: Decreased survival among sedentary patients undergoing dialysis: results from the Dialysis Morbidity and Mortality Study wave 2. Am J Kidney Dis 2003;41:447-454.
47 Kovesdy CP, Anderson JE: Reverse epidemiology in patients with chronic kidney disease who are not yet on dialysis. Semin Dial 2007; 20:566-569.

48 Horwich TB, Fonarow GC: Reverse epidemiology beyond dialysis patients: chronic heart failure, geriatrics, rheumatoid arthritis, COPD, and AIDS. Semin Dial 2007;20:549553.

49 Horwich TB, Fonarow GC: Measures of obesity and outcomes after myocardial infarction. Circulation 2008;118:469-471.

50 Artham S, Lavie CJ, Patel DA, Ventura H: The obesity paradox: higher body fat predicts better prognosis in heart failure and coronary patients - a review of Ochsner studies. Obesity 2008;16:S117-S118.

51 Artham SM, Lavie CJ, Milani RV, Ventura HO: The obesity paradox: impact of obesity on the prevalence and prognosis of cardiovascular diseases. Postgrad Med 2008;120: 34-41. 